\title{
Model Bimbingan Kelompok dengan Menggunakan Metode Diskusi untuk Mengurangi Kejenuhan Belajar Peserta Didik
}

\author{
Nursilviani ${ }^{1 凶}$ Fitria Kasih $^{1}$, Rici Kardo ${ }^{1}$ \\ (1) Bimbingan Konseling Islam, STKIP PGRI Sumatera Barat
}

$\triangle$ Corresponding author

(nursilviani1234@gmail.com)

Abstrak

Penelitian ini dilatarbelakangi adanya kejenuhan belajar peserta didik dan masih adanya guru Bimbingan Konseling yang belum menggunakan metode yang bervariasi dalam melaksanakan bimbingan kelompok. Tujuan penelitian ini adalah mendeskripsikan: 1). Profil kejenuhan belajar peserta didik, 2). Pelaksanaan bimbingan kelompok oleh guru BK mengunakan metode diskusi, 3). Model rancangan layanan bimbingan kelompok dengan menggunakan metode diskusi untuk mengurangi kejenuhan belajar peserta didik. Penelitian ini dilakukan dengan menggunakan mixed method. Teknik pengambilan sample menggunakan purposive sampling dengan 33 partisipan. Sedangkan penelitian kualitatif, informan kunci penelitian yaitu $1 \mathrm{Guru}$ Bimbingan Konseling kelas XI IPS 1 dan 2 orang informan tambahan. Instrumen yang di gunakan yaitu angket dan pedoman wawancara. Teknik analisis yang digunakan dalam pengolahan data menggunakan presentase. Untuk analisis data kualitatif melalui reduksi data, penyajian data dan penarikan kesimpulan. Berdasarkan hasil penelitian tentang kejenuhan belajar peserta didik kelas XI IPS 1 di SMAN 1 VII Koto Sungai Sarik dilihat dari: 1) Secara umum profil kejenuhan belajar peserta didik pada kategori rendah. 2) Pelaksanaan layanan bimbingan kelompok untuk mengurangi kejenuhan belajar peserta didik yang dilakukan guru bimbingan dan konseling belum memberikan hasil yang maksimal karena belum menggunakan metode-metode yang bervariasi. 3) Model ditemukan bahwa masih adanya peserta didik yang mengalami kejenuhan belajar dan pelaksanaan bimbingan kelompok masih belum bervariasi. Model rancangan layanan bimbingan kelompok untuk mengurangi kejenuhan belajar peserta didik. Dapat diambil kesimpulan sebagai berikut: kejenuhan belajar peserta didik berada kategori rendah dan belum berada pada kategori sangat tinggi.

Kata Kunci: Bimbingan Kelompok, Metode Diskusi, Kejenuhan Belajar, Peserta Didik

\begin{abstract}
This research is motivated by the saturation of learning by students and the existence of Guidance Counseling teachers who have not used various methods in implementing group guidance. The purpose of this study is to describe: 1). Profile of student learning saturation, 2). Implementation of group guidance by BK teachers using the discussion method, 3). The group guidance service design model uses the discussion method to reduce student learning saturation. This research was conducted using a mixed method. The sampling technique used purposive sampling with 33 participants. While the qualitative research, the key informants of the research are 1 Guidance Counseling Teacher for class XI IPS 1 and 2 additional informants. The instruments used are questionnaires and interview guidelines. The analysis technique used in data processing uses percentages. For qualitative data analysis through data reduction, data presentation and drawing conclusions. Based on the results of research on learning saturation of class XI IPS 1 students at SMAN 1 VII Koto Sungai Sarik seen from: 1) In general, the profile of student learning saturation is in the low category. 2) The implementation of group guidance services to reduce student learning boredom by guidance and counseling teachers has not given maximum results because they have not used various methods. 3) The model found that there were still students who experienced learning saturation and the implementation of group guidance did not vary. Group guidance service design model to reduce student learning saturation. It can be concluded as follows: the learning saturation of students is in the low category and not yet in the very high category.

Keywords: Group Guidance, Discussion Method, Learning Saturation, Students
\end{abstract}




\section{PENDAHULUAN}

Pendidikan adalah sarana yang dapat mengubah seseorang dari kebodohan dan hal-hal yang ditimbulkan dari kebodohan tersebut, seperti memiliki pengetahuan yang minim, pola pikir yang sempit, tingkah laku yang kurang baik, kemiskinan, mudah ditipu dan sebagainya. Semakin tinggi pendidikannya maka semakin berpeluang untuk mendapatkan pekerjaan yang bagus, kedudukan yang diinginkan, mendapatkan karir dan kehidupan yang lebih baik. Pendidikan juga dapat menjadikan manusia mempunyai banyak ilmu pengetahuan, pengalaman dan mengubah tingkah laku individu. Pendidikan yang berhasil akan menciptakan manusia yang pantas dan berlayakan di masyarakat dan untuk mencetak manusia yang memiliki berkualitas dan berdaya asing.

Pembelajaran yang berhasil ditandai dengan antusiasme dan semangat peserta didik dalam mengikuti proses pembelajaran. Faktor lain yang mendukung proses pembelajaran adalah suasana belajar yang tidak membosankan dan aktivitas yang membuat peserta didik senang serta tidak merasa jenuh dalam belajar. Kejenuhan belajar kerap kali membuat peserta didik mengalami tingkat stres yang tinggi dan stres yang berkepanjangan yang dialami oleh remaja dapat meyebabkan terjadinya kejenuhan belajar pada peserta didik. Kondisi kejenuhan belajar peserta didik harus segera ditangani, jika tidak dan dibiarkan begitu saja maka kegiatan belajar peserta didik tidak akan berjalan efektif, mengalami kemunduran dalam hal tercapai tujuan belajar, serta berdampak ke hal yang lebih lanjut yakni ke jenjang perguruan tinggi. Dibutuhkan penanganan yang lebih tepat, salah satunya melalui layanan bimbingan dan konseling di sekolah. Salah satu layanan bimbingan konseling untuk membantu mengurangi kejenuhan belajar peserta didik yaitu dengan bimbingan kelompok.

Menurut Kasih (2017:14) bimbingan dan konseling merupakan proses pemberian bantuan yang diberikan kepada individu-individu dalam upaya membantu individu dalam mencapai tugastugas perkembangannya sehingga dapat tercapai perkembangan yang optimal. Dalam rangka mewujudkan suksesnya program pendidikan di sekolah. Dalam pelaksanaannya bimbingan dan konseling merupakan salah satu unsur penunjang keberhasilan program pendidikan di sekolah, pelayanan bimbingan dan konseling berperan dalam aspek pengembangan diri peserta didik guna mencapai pengembangan diri yang optimal sejalan dengan tujuan pendidikan. Maka hal itu dapat dilakukan melalui pelayanan bimbingan dan konseling yang bermutu.

Salah satu pelayanan bimbingan dan konseling yaitu bimbingan kelompok, bimbingan kelompok merupakan proses bantuan yang diberikan guru BK kepada peserta didik atau konseli dengan cara membentuk kelompok kecil yang terdiri dari pemimpin kelompok yaitu guru BK dan anggota kelompok yaitu konseli atau peserta didik yang terdiri dari 8-12 anggota kelompok tujuannya untuk melatih kemampuan komunikasi, perilaku sosial dan menyelesaikan permasalahan ataupun membahas permasalahan terkini yang bersifat tidak rahasia. Masalah yang menjadi topik pembicaraan dalam layanan bimbingan kelompok, dibahas melalui suasana dinamika kelompok secara intens dan konstruktif, diikuti oleh semua anggota kelompok di bawah bimbingan pemimpin kelompok. Dalam kegiatan layanan bimbingan kelompok dapat terjadi saling tukar pengalaman di antara para anggota yang dapat berpengaruh terhadap perubahan tingkah laku individu.

Menurut Tohirin (2015:164) bimbingan kelompok merupakan suatu cara memberikan bantuan (bimbingan) kepada individu (peserta didik) melalui kegiatan kelompok. Dalam layanan bimbingan kelompok aktifitas dan dinamika kelompok harus diwujudkan untuk membahas berbagai hal yang berguna bagi pengembangan atau pemecahan masalah individu (peserta didik) yang menjadi peserta layanan. Bimbingan kelompok adalah layanan bimbingan yang diberikan dalam suatu kelompok. Bimbingan kelompok memanfaatkan dinamika kelompok untuk menuntaskan halhal yang berguna bagi pengembangan pribadi dan juga dapat membantu untuk menuntaskan masalah individu yang menjadi peserta kegiatan kelompok.

Ajeng, dkk (2020:4) menyatakan bahwa metode diskusi merupakan suatu pertemuan dua orang atau lebih yang diajukan untuk saling tukar pengalaman dan pendapat, biasanya menghasilkan keputusan bersama. Peserta didik yang mengikuti kegiatan bimbingan kelompok dengan teknik diskusi dapat memanfaatkan dinamika kelompok untuk saling bertukar pendapat dalam membahas topik tertentu yang menjadi perhatian kelompok dengan menghasilkan keputusan bersama, seperti motivasi belajar sehingga kebutuhan-kebutuhan yang selama ini belum terpenuhi yang mengakibatkan peserta didik memiliki motivasi rendah. 
Metode diskusi kelompok adalah suatu cara yang dilakukan masing-masing anggota kelompok untuk menyampaikan pemikirannya dalam kelompok guna mendapatkan suatu kesimpulan dan bahan yang sedang dibahas dan menghasilkan sebuah keputusan yang akan disepakati oleh anggota kelompok. Kegiatan diskusi memungkinkan peserta didik untuk secara aktif berkomunikasi dengan anggota kelompok lain serta bertukar gagasan yang pada akhirnya peserta didik akan memiliki tingkat pemahaman yang baik terhadap suatu permasalahan yang sedang dibahas.

Menurut Trianto (Hermawan \& Subagyo 2017: 40-41) belajar adalah suatu proses yang ditandai dengan adanya perubahan pada diri seseorang. Perubahan sebagai hasil dari proses belajar dapat diindikasikan dalam berbagai bentuk seperti berubah pengetahuan, pemahaman, sikap dan tingkah laku, kecakapan, keterampilan dan kemampuan, serta perubahan aspek-aspek yang lain yang ada pada individu yang belajar. Belajar mengandung pengertian terjadinya perubahan dari persepsi dan perilaku, termasuk juga perbaikan perilaku misalnya pemuasan kebutuhan masyarakat dan pribadi secara lebih lengkap.

Hamzah, dkk (2017: 8) mengemukakan bahwa kejenuhan belajar adalah masalah yang banyak dialami peserta didik dimana akibat serius dari masalah tersebut adalah lemahnya motivasi belajar, timbulnya rasa malas yang berat dan menurunnya prestasi belajar. Sering kita menemukan peserta didik yang mengalami hambatan belajar. la sulit meraih prestasi, padahal telah mengikuti pelajaran dengan sungguh-sungguh. Bahkan ditambah dengan tugas tambahan di rumah, tetapi hasilnya tetap kurang memuaskan. Sehingga peserta didik terkesan lambat mengerjakan tugas yang berhubungan dengan kegiatan belajar. Mereka tampak malas, mudah putus asa, acuh tak acuh, jenuh dan bosan.

Menurut Schaufeli \& Enzmann (Vitasari, 2016:60) karakteristik dari kejenuhan belajar yaitu 1) Kelelahan emosi seperti perasaan depresi, rasa sedih, kelelahan emosional, kemampuan mengendalikan emosi, ketakutan yang tidak berdasar dan kecemasan. 2) Kelelahan fisik yaitu gejala yang terjadi pada kelelahan fisik adalah seperti sakit kepala, mual, pusing, gelisah, otot-otot sakit, gangguan tidur, penurunan berat badan, kurangnya nafsu makan, sesak napas, kelelahan kronis, kelemahan tubuh, tekanan darah tinggi. 3) Kelelahan kognitif yaitu ketidakberdayaan, kehilangan harapan dan makna hidup, ketakutan dirinya menjadi "gila", perasaan tidak berdaya dan dirinya tidak mampu untuk melakukan sesuatu, perasaan gagal yang selalu menghantui, penghargaan diri yang rendah, munculnya ide bunuh diri, ketidakmampuan untuk berkonsentrasi, lupa, tidak dapat mengerjakan tugas-tugas yang kompleks, kesepian, penurunan daya tahan dalam menghadapi frustasi yang dirasakan. 4) Kehilangan motivasi yaitu kehilangan semangat, kehilangan idealisme, kecewa, pengunduran diri dari lingkungan, kebosanan dan demoralisasi.

Berdasarkan hasil wawancara pada Tanggal 24 april 2021 dengan salah satu guru BK di SMAN 1 VII Koto Sungai Sarik peneliti mendapatkan informasi bahwasannya terdapat peserta didik yang mengalami kejenuhan belajar yaitu peserta didik merasa malas mengikuti proses pembelajaran, tidak dapat mengingat kembali pelajaran yang telah dijelaskan oleh guru, kehilangan semangat belajar, tidak fokus atau konsentrasi saat belajar, tidak tertarik terhadap mata pelajaran tertentu dan peserta didik mengeluh karena suasana belajar yang tidak berubah-ubah. Guru BK telah berupaya untuk mengurangi kejenuhan belajar peserta didik dengan memberikan beberapa layanan bimbingan dan konseling untuk menghilangkan kejenuhan belajar seperti layanan informasi, konseling individual dan konseling kelompok tetapi usaha guru BK belum tercapai dengan baik, guru BK sudah melakukan bimbingan kelompok menggunakan metode diskusi tetapi belum terkait kejenuhan belajar.

Berdasarkan observasi yang dilakukan pada Tanggal 24 April 2021 di SMAN 1 VII Koto Sungai Sarik bahwa terdapat peserta didik yang selalu keluar masuk kelas pada saat proses belajar mengajar, tidur di kelas, tampak lesu pada saat guru menjelaskan materi, terlambat masuk kelas, selalu bermain hanphone saat proses belajar mengajar, membolos, tidak dapat menjawab pertanyaan guru, selalu membuat keributan di kelas, selalu melamun atau tidak konsentrasi pada saat proses belajar mengajar, tidak mengerjakan tugas pekerjaan rumah (PR), sering mengganggu temannya saat guru menjelaskan materi. 
Berdasarkan obervasi dan hasil wawancara peneliti ingin melakukan penelitian tentang "Model Bimbingan Kelompok dengan Menggunakan Metode Diskusi untuk Mengurangi Kejenuhan Belajar Peserta Didik di Kelas XI IPS 1 SMAN 1 VII Koto Sungai Sarik".

\section{METODE PENELITIAN}

Berdasarkan batasan masalah dan tujuan penelitian yang dirumuskan, maka penelitian ini berjenis penelitian mixedmethod. (Sugiyono (2016: 404-405) menyatakan bahwa metode penelitian yang mengombinasikan atau menggabungkan antara metode kuantitatif dan metode kualitatif untuk digunakan secara bersama-sama dalam suatu kegiatan penelitian, sehingga diperoleh data yang lebih komprehensif, valid, reliable dan objektif. Data yang komprehensif adalah data yang lengkap yang merupakan kombinasi antara data kuantitatif dan kualitatif. Data yang valid adalah data yang memiliki derajat ketepatan yang tinggi antara data yang sesungguhnya terjadi dengan data yang dapat dilaporkan oleh peneliti. Melalui kombinasi dua metode, maka data yang diperoleh dari peneliti akan lebih valid, karena data yang kebenarannya tidak dapat divalidasi dengan metode kuantitatif akan divalidasi dengan metode kualitatif atau sebaliknya. Berdasarkan teori tersebut peneliti akan mendeskripsikan mengenai model bimbingan kelompok dengan menggunakan metode diskusi untuk mengurangi kejenuhan belajar peserta didik di kelas XI IPS 1 SMAN 1 VII Koto Sungai Sarik.

\section{HASIL DAN PEMBAHASAN}

Sesuai dengan variabel penelitian dalam deskripsi data hasil penelitian ini akan dibahas tentang model bimbingan kelompok dengan menggunakan metode diskusi untuk mengurangi kejenuhan peserta didik di kelas XI IPS 1 SMAN 1 VII Koto Sungai Sarik. Hasil penelitian menunjukkan bahwa kejenuhan belajar peserta didik yang terdapat pada 33 orang peserta didik yaitu berada pada kategori sangat rendah yaitu 1 orang dengan jumlah presentase (3,03\%), peserta didik pada kategori rendah berjumlah 19 orang dengan jumlah presentase (57,58), peserta didik pada kategori cukup tinggi yaitu 9 orang dengan jumlah presntase (27,27\%), pada kategori tinggi terdapat 4 peserta didik dengan presentase (12,12\%), sedangkan pada kategori sangat tinggi yaitu 1 dengan presentase $(3,70)$. Artinya sebagian besar peserta didik mengalami kejenuhan belajar pada kategori rendah.

Menurut (Vitasari 2013) kejenuhan belajar adalah kondisi dimana seseorang lelah secara fisik dan emosi karena banyaknya tanggung jawab dan tugas-tugas yang harus diselesaikan dalam kurun waktu yang telah ditetapkan sehingga seseorang tersebut tidak dapat menyelesaikan tugas-tugasnya dengan baik. Kelelahan fisik dan emosi membuat tingkat kecemasan anak meningkat berkali-kali lipat, mereka akan melalaikan tugas-tugas yang seharusnya mereka kerjakan hal ini tentu saja akan berdampak pada hasil belajar anak. Selanjutnya akan dibahas perindikator:

\section{Kelelahan emosi}

Dari hasil penelitian dapat diketahui kejenuhan belajar peserta didi kelas XI IPS 1 SMA N 1 VII Koto Sungai Sarik berdasarkan kelelahan emosi dari 33 peserta didik. 1 orang berada pada kategori sangat rendah dengan jumlah presentase (3,23\%). 7 berada pada katerogi rendah dengan jumlah presentase (22,58\%). 16 orang berada pada kategori cukup tinggi dengan jumlah presentase (51,61\%). 6 orang berada pada kategori tinggi dengan jumlah presentase (19,35\%). Sedangkan 1 orang berada pada kategori sangat tinggi dengan jumlah presentase (3,23\%).

Maslach dan Jackson (1981: 99) dalam (Alifandi, Yanuar 2016:15) menyatakan bahwa kelelahan emosional adalah suatu perasaan emosional yang berlebihan dan sumber daya emosional seseorang yang telah habis yang dialirkan oleh kontak seseorang dengan individu lain. Hal ini menunjukan bahwa kelelahan emosi muncul diakibatkan oleh adanya kontak dengan orang lain yang menguras sumber daya emosinya. Berdasarkan definisi kelelahan yang telah dijelaskan sebelumnya, maka kelelahan emosi ini merupakan keadaan penurunan sumberdaya emosi yang dialirkan karena kontak dengan individu lain. Kelelahan emosi. Gejala yang terjadi pada kelelahan emosi adalah seperti perasaan depresi, rasa sedih, kelelahan emosional, kemampuan mengendalikan emosi, ketakutan yang tidak berdasar, dan kecemasan. 


\section{Kelelahan fisik}

Berdasarkan hasil analisis dapat diketahui kejenuhan belajar peserta didik dilihat dari indikator kelelahan emosi kejenuhan belajar peserta didik dilihat dari indikator kelelahan emosi dari 33 peserta didik. 1 orang berada pada kategori sangat rendah dengan jumlah presentase (3,23\%). 7 berada pada katerogi rendah dengan jumlah presentase $(22,58) .16$ orang berada pada kategori cukup tinggi dengan jumlah presentase (51,61). 6 orang berada pada kategori tinggi dengan jumlah presentase $(19,35)$. Sedangkan 1 orang berada pada kategori sangat tinggi dengan jumlah presentase $(3,23)$. Menurut Santoso (2004) dalam bahwa kelelahan terjadi akibat kontraksi otot rangka yang lama dan kuat, dimana proses metabolisme tidak mampu lagi meneruskan supply energi yang dibutuhkan serta membuang sisa metabolisme, khususnya asam laktat. Jika asam laktat yang banyak terkumpul, otot akan kehilangan kemampuannya. Terbatasnya aliran darah pada otot (ketika berkontraksi), otot menekan pembuluh darah dan membawa oksigen sehingga menyebabkan terjadinya kelelahan. Kelelahan fisik adalah kelelahan yang berhubungan dengan fisik dan stamina fisik. Sakit fisik yang dirasakan seperti sakit kepala, sakit punggung, susah tidur, gelisah, dan perubahan pola makan.

\section{Kelelahan kognitif}

Kejenuhan belajar peserta didik dilihat dari indikator kelelahan kognitif. 1 berada pada kategori sangat rendah dengan jumlah presentasi (3,33\%). 2 orang berada pada kategori rendah dengan jumlah presentase (6,67\%). 13 orang berada pada kategori cukup tinggi dengan jumlah presentaese (43,33\%). 12 orang berada pada kategori tinggi dengan jumlah presentase $(40,00 \%)$. Sedangkan pada kategori sangat tinggi terdapat 2 orang dengan presentase (6,67). Kelelahan kognitif adalah kelelahan yang merupakan akibat dari kerja mental seperti kejemuan sebab kurangnya minat. Gejala yang terjadi pada kelelahan kognitif adalah seperti ketidakberdayaan, kehilangan harapan dan makna hidup, perasaan tidak berdaya dan dirinya tidak mampu untuk melakukan sesuatu, perasaan gagal yang selalui menghantui, penghargaan diri yang rendah, munculnya ide diri yang rendah, kidakmampuan untuk berkonsentrasi, lupa, tidak dapat mengerjakan tugas- tugas yang kompleks, kesepian, penurunan daya tahan dalam menghadapi frustasi yang dirasakan.

\section{Kurangnya motivasi}

Kejenuhan belajar peserta didik dilihat dari indikator kurangnya motivasi. 0 berada pada kategori sangat rendah dengan jumlah presentasi $(0,00 \%) .5$ orang berada pada kategori tinggi dengan jumlah presentase (16,67\%). 9 orang berada pada kategori cukup tinggi dengan jumlah presentaese (30,00\%). 12 orang berada pada kategori rendah dengan jumlah presentase $(40,00 \%)$. Sedangkan pada kategori sangat rendah terdapat 4 orang dengan presentase (13,33\%). Lemahnya motivasi untuk belajar dalam diri peserta didik itu sendiri merupakan faktor utama yang dialami oleh kebanyakan peserta didik, sehingga hal ini menyebabkan peserta didik kurang berminat untuk belajar dan menghabiskan waktu beberapa tahun di sekolah dengan sia-sia. Peserta didik yang tidak memiliki impian dan cita-cita yang jelas, peserta didik yang tidak percaya diri dan merasa dirinya tidak pintar, peserta didik yang memiliki idealisme yang menganggap tujuan akhir pendidikan adalah hanya untuk mendapatkan pekerjaan saja yang pada akhirnya peserta didik tidak serius dalam hal pembelajaran, akan membuat peserta didik menjadikan pendidikan sebagai formalitas semata.

\section{KESIMPULAN}

Berdasarkan analisis data dan pembahasan dapat diambil kesimpulan mengenai model bimbingan kelompok dengan menggunakan metode diskusi untuk mengurangi kejenuhan belajar peserta didik di kelas XI IPS 1 SMAN 1 VII Koto Sungai Sarik. Temuan penelitian ini dapat disimpulkan sebagai berikut: 1) Secara umum profil kejenuhan belajar peserta didik berada pada kategori rendah yaitu secara keseluruhan. Pada indikator kelelahan emosi yaitu pada kategori cukup tinggi, pada indikator kelelahan fisik yaitu pada kategori cukup tinggi, pada indikator kelelahan kognitif yaitu pada kategori cukup tinggi, pada indikator kurangnya motivasi yaitu berada pada kategori tinggi. 2) Pelaksanaan bimbingan kelompok dalam membantu mengurangi kejenuhan belajar yang dilakukan Guru Bk cenderung kurang efektif layanannya, dan Guru BK diharapkan lebih kreatif dalam pemberian layanan bimbingan kelompok lanjutan di SMAN 1 VII Koto Sungai Sarik. 3) 
Model rancangan layanan bimbingan kelompok dengan menggunakan metode diskusi untuk mengurangi kejenuhan belajar belum pernah melakukan layanan bimbingan kelompok menggunakan metode diskusi, maka peneliti berharap agar Guru BK dapat mengaplikasikan metode diskusi yang peneliti rancang di SMAN 1 VII Koto Sungai Sarik.

\section{DAFTAR RUJUKAN}

Gempur, Santoso. 2004. Manajemen Keselamatan dan Kesehatan Kerja. Jakarta: Prestasi Pustaka Hamzah, dkk. 2017. Efektifitas Konseling Kelompok dengan Teknik Relaksasi Religius untuk Mengurangi Kejenuhan Belajar Mahasiswa. Jurnal Bimbingan Konseling. Vol. 6, No. 1.

Hermawan \& Subagyo. 2017. Peningkatan Aktifitas dan Hasil Belajar dengan Metode Problem Basic Learning (Pbl) Pada Mata Pelajaran Tune Up Motor Bensin Siswa Kelas Xi Di Smk Insan Cendekia Turi Sleman Tahun Ajaran 2015/2016. Jurnal Taman Vokasi. Vol. 5, No. 1.

Kasih, Fitria. 2017. Profil Kompetensi Guru Bimbingan dan Konseling dalam Pelayanan Kelompok di SMA Sumatera Barat. Jurnal Counseling Care. Vol. 1, No. 1.

Sugiyono. (2016). Metode Penelitian Kuantitatif, Kualitatif dan R\&D. Bandung: PT Alfabet.

Tohirin. 2015. Bimbingan dan Konseling di Sekolah dan Madrasah (Berbasis Integrasi). Jakarta: Raja Grafindo Persada.

Vitasari, Ita. 2016. Kejenuhan Belajar Ditinjau dari Kesepian dan Kontrol Diri Siswa Kelas Xi Sman 9 Yogyakarta. E-Journal Bimbingan dan Konseling. Vol. 7 No. 5.

Yanuar Alifandi , 1511411079 (2016) Kelelahan Emosi (Emotional Exhaustion) Pada Mahasiswa Yang Bekerja Paruh Waktu (Studi Pada Mahasiswa Universitas Negeri Semarang Yang Bekerja Paruh Waktu). Under Graduates thesis, Universitas Negeri Semarang. 